\title{
ANALISIS USULAN PERANCANGAN TATA LETAK PABRIK DI CV. ATHAM TOYS
}

\author{
Mohammad Edo Setiawan, Ratu Siti Khodijah, Rizki Gema Ramadhan \\ Universitas Al-Azhar Indonesia \\ e-mail: m.edosetiawan@gmail.com; ratusk@gmail.com; rizkygema97@gmail.com
}

\begin{abstract}
ABSTRAK
Penggunaan sumber daya yang efisien pada perusahaan memiliki tata letak perusahaan yang baik dapat meningkatkan produktivitas yang bertujuan untuk menghasilkan profit dan meningkatkan efektivitas pekerjaan. Perancangan tata letak ini meliputi posisi dan pengaturan tata letak fasilitas-fasilitas setiap operasi dalam memanfaatkan area yang ada untuk penempatan bahan-bahan. Penggunaan ruangan akan menjadi efisien apabila fasilitas yang disusun dengan mempertimbangkan jarak minimal antar fasilitas produksi maupun perpindahan materialnya. Pada penelitian kali ini, objek yang diteliti adalah tata letak pabrik dari alur produksi produk mainan kayu. Produk ini diproduksi oleh CV. Atham Toys. Berdasarkan pengamatan yang dilakukan, dipilih metode Graph Based Construction sebagai acuan dengan jarak rectilinier terkecil. Kemudian didapatkan luas keseluruhan pabrik yang terdiri dari luas lantai produksi, luas fasilitas lainya dan efisiensi. Penentuan lokasi pabrik yang dilakukan berdasarkan kriteria yang dinilai oleh 4 pakar dan diolah dengan menggunakan metode Analytical Hierarchy Process. Lokasi pabrik yang paling strategis adalah di Tangerang.
\end{abstract}

Kata kunci: Perpindahan Material, Tata Letak Fasilitas, Tata Letak Pabrik.

\begin{abstract}
The efficient use of resources in a company having a good corporate layout can increase productivity aimed at generating profits and increasing work effectiveness. This layout design includes the position and layout of facilities for each operation in utilizing the existing area for placement of materials. The use of space will be efficient if the facilities are arranged by considering the minimum distance between production facilities and the transfer of material. In this study, the object under study is the factory layout of the production path of wooden toy products. This product is produced by CV. Atham Toys. Based on observations, the Graph Based Construction method was chosen as a reference with the smallest rectilinear distance. Then the overall area of the factory consists of the production floor area, other facilities and efficiency. Determination of factory location is based on criteria assessed by 4 experts and processed using the Analytical Hierarchy Process method. The most strategic factory locations is in Tangerang.
\end{abstract}

Keywords: Material Transfer, Facility Layout, Factory Layout.

\section{PENDAHULUAN}

Tata letak atau pengaturan dari fasilitas produksi dan area kerja yang ada merupakan landasan utama dalam dunia industri. Pada umumnya tata letak pabrik yang terencana dengan baik akan ikut menentukan efisiensi dan dalam beberapa hal akan juga menjaga kelangsungan hidup ataupun kesuksesan kerja suatu industri. Dalam membangun suatu perusahaaan harus sesuai dengan perencanaan dan perancangan yang sesuai dengan syarat pendirian suatu perusahaan. Dengan adanya perencanaan dan perancangan tata letak fasilitas ini, diharapkan agar aliran proses serta pemindahan bahan yang ada di dalam suatu perusahaan berjalan dengan lancar.

Kelancaran proses produksi dapat meminimumkan biaya dan mengoptimalkan keuntungan yang diperoleh. Selain itu, perencanaan dan perancangan tata letak fasilitas ini juga berguna untuk mengoptimalkan hubungan antar aktivitas. CV. Atham Toys adalah sebuah perusahaan yang memproduksi mainan berbahan dasar kayu. Pabriknya berlokasi di daerah BSD, Tangerang. Mainan yang diproduksi biasanya akan dikirimkan kepada toko yang dikelola oleh perusahaan itu sendiri untuk dijual. Penelitian dilakukan ditempat 
tersebut karena tata letak lantai produksi masih kurang efektif dan efisien sehingga membuat proses produksi menjadi lambat dengan jumlah demand yang sudah cukup tinggi. Maka dari itu perlu dilakukan tata letak ulang sehingga produktivitas akan meningkat dan profit yang diharapkan akan tercapai.

\section{TINJAUAN PUSTAKA}

\section{Tata Letak Pabrik}

Tata letak pabrik adalah masalah yang kerap kali kita jumpai dalam teknik industri. Dalam suatu pabrik, tata letak dari fasilitas produksi dan area kerja merupakan elemen dasar yang sangat penting dari kelancaran proses produksi. Masalah yang paling utama adalah apakah pengaturan dari semua fasilitas produksi tersebut telah dibuat sebaikbaiknya sehingga bisa mencapai suatu proses produksi yang paling efisien dan bisa mendukung kelangsungan serta kelancaran proses produksi secara optimal.

Sesederhana apapun itu, pada saat kita memindahkan suatu barang atau fasilitas untuk mempermudah proses pengerjaan dapat disebut sebagai pengaturan tata letak fasilitas. Tata letak pabrik yang terencana dengan baik akan ikut menentukan efisiensi dan efektivitas kegiatan produksi dan dalam beberapa hal akan juga menjaga kelangsungan hidup atau keberhasilan suatu perusahaan. Peralatan produksi yang canggih dan mahal harganya akan tidak berarti apa-apa akibat perencanaan tata letak yang sembarangan saja [1].

\section{Tata Letak Fasilitas}

Perancangan tata letak fasilitas merupakan perancangan fasilitas-fasilitas yang terdapat di pabrik seperti kantor, dapur, cafeteria, koperasi dan lain sebagainya. Tata letak fasilitas didefinisikan sebagai rnenganalisis. Membentuk konsep, merancang, dan mewujudkan sistem bagi pembuatan barang atau jasa. Kegiatan perancangan fasilitas berhubungan dengan perancangan susunan unsur fisik suatu lingkungan [2].

\section{Perencanaan Proses}

Perencanaan proses adalah fungsi di dalam proses manufacturing yang menetapkan proses dan parameter apa yang digunakan untuk merubah part awal menjadi part akhir, yang didahului adanya gambar teknik. Proses planning merupakan penentuan proses perakitan dan pembuatan dan pengurutan dimana proses ini harus diselesaikan untuk menyelesaikan prosduk dari bentuk awal sampai bentuk akhir [1].

\section{Usulan Luas Lantai Produksi}

Usulan luas lantai produksi berguna dalam memperkirakan alokasi ruang yang dibutuhkan dalam menempatkan berbagai fasilitas yang digunakan pada lantai produksi [3].

\section{Material Handling Planning Sheet (MHPS)}

Material Handling Planning Sheet (MHPS) merupakan suatu tabel yang digunakan untuk menghitung biaya penanganan bahan. Disini dilakukan minimasi biaya penanganan bahan tetapi dengan tidak mengabaikan prinsip-prinsip pemindahan bahan,prinsip-prinsip tersebut adalah seluruh aktivitas pemindahan harus direncanakan, mengoptimasi aliran bahan dengan merencanakan sebuah urutan operasi dan pengaturan peralatan yang digunakan, mengurang mengkombinasi dan menghilangkan pergerakan atau peralatan yang tidak diperlukan, memanfaatkan prinsip gravitasi bagi pergerakan bahan jika memungkinkan, meningkatkan jumlah, ukuran dan berat muatan yang dipindahkan, menggunakan peralatan pemindahan yang mekanis dan otomatis, mengurangi waktu non produktif dari peralatan dan tenaga kerja [2]. 


\section{HASIL DAN PEMBAHASAN}

\section{Spesifikasi Produk}

Pada penelitian ini, digunakan suatu produk mainan kayu sebagai objek penelitian. Produk tersebut memiliki ukuran panjang $30 \mathrm{~cm}$, lebar 10, dan tinggi $8 \mathrm{~cm}$. Adapun berat produk ini adalah 560 gram. Bagian-bagian dalam produk ini antara lain bagian base, pasak tiang kayu, dan bagian biji. Berikut (Gambar 1) adalah foto produk tersebut.

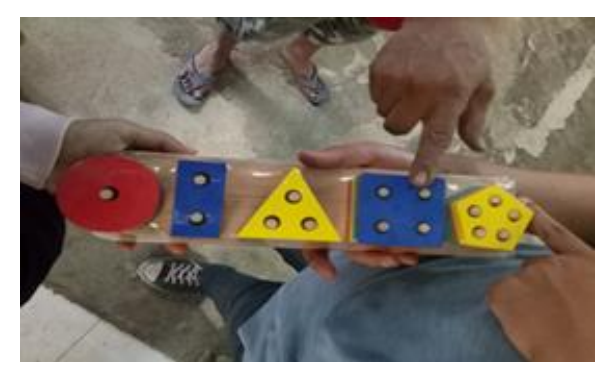

Gambar 1. Spesifikasi Produk Mainan Geometrik 5 Tumpuk

\section{Bill of Material (BOM)}

Pada BOM yang sudah diuraikan dapat memberikan informasi mengenai sub material yang digunakan dalam membuat mainan tersebut dan material digambarkan dengan Multi Level dengan jumlah 3 Level. Pada Level 0 yaitu Mainan Geometrik 5 Tumpuk, Level 1 Base Mainan, Pasak Tiang Kayu, Biji Mainan dan Plastik Wrapping. Adapun Level 2 yakni Kayu Jati Belanda dan Cat Pernish, Kayu Ramin, serta Kayu MDF dan Cat Water Base. Berikut adalah BOM dari produk tersebut yang ditunjukkan pada Gambar 2 dan keterangannya terdapat pada Tabel 1.

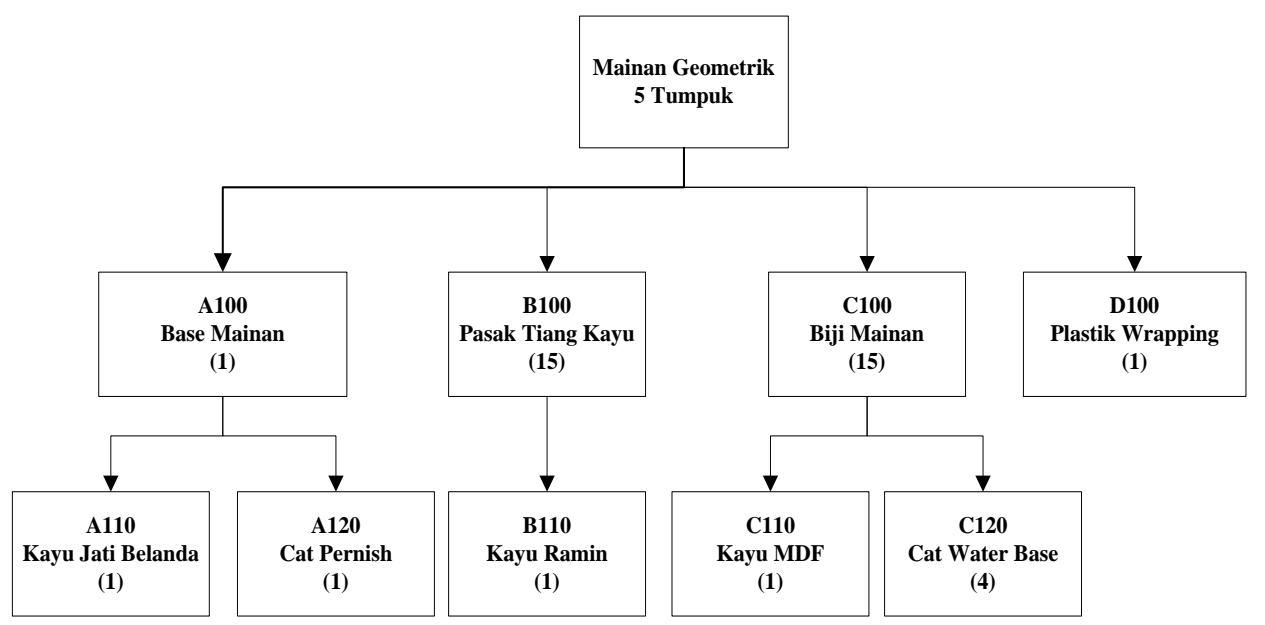

Gambar 2. Bill Of Material Mainan Geometrik 5 Tumpuk

Tabel 1. Bill Of Material List Mainan Geometrik 5 Tumpuk

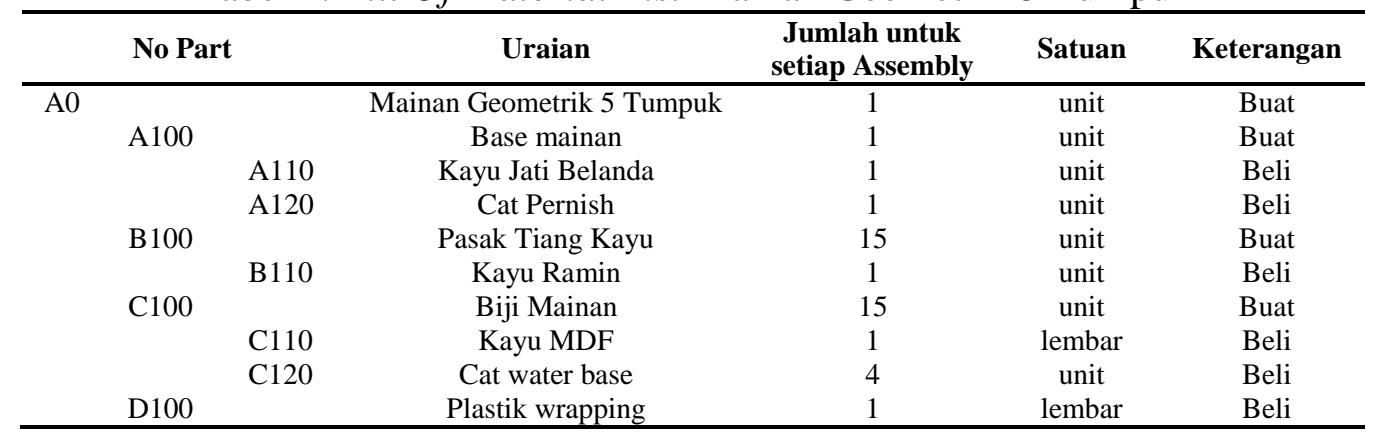




\section{Operation Process Chart (OPC)}

Pada penelitian kali ini, telah dibuat perencanaan proses salah satu tahap pertama kali yang dilakukan adalah pembuatan OPC (Operation Prosses Chart). OPC yang dibuat untuk membantu setiap operator dalam melakukan pekerjaan sesuai dengan urutan prosesnya. Pada produk yang dibuat, terdapat 3 bagian yaitu bagian base, bagian pasak, dan bagian biji. Berdasarkan pada OPC yang dibuat pada proses pembuatan mainan geometrik 5 tumpuk memiliki proses sebanyak 22 operasi, dan 3 inspeksi (pemeriksaan). Total pada pembuatan satu mainan geometrik 5 tumpuk yaitu selama 123 menit dengan waktu proses 113 menit dan waktu inspeksi 11 menit.

\section{Routing Sheet}

Routing Sheet berguna untuk menghitung jumlah mesin yang dibutuhkan dan untuk menghitung jumlah part yang harus dipersiapkan dalam usaha memperoleh sejumlah produk jadi yang diinginkan. Routing Sheet adalah tabulasi langkah-langkah yang harus dilakukan dalam memproduksi komponen-komponen tertentu. Routing Sheet memberikan informasi seperti jumlah demand schedule, demand expected, jumlah mesin yang dibutuhkan dari proses produksi.

\section{Multi Product Process Chart (MPPC)}

MPPC (Multi Product Process Chart) adalah suatu diagram yang menunjukkan urutan untuk masing-masing komponen yang akan diproduksi. Peta MPPC juga dapat berguna sebagai gambaran umum yang berkaitan dengan langkah-langkah pengerjaan dari setiap produk yang ada pada waktu proses tertentu sehingga diperoleh informasi tentang kesamaan proses dari setiap produk dengan yang lainya. Berdasarkan MPPC juga dapat diketahui aliran balik (back tracking) dan pola aliran yang tidak sesuaidengan urutan proses.

\section{Luas Lantai Produksi}

Dengan menggambarkan peta MPPC dan perhitungan yang dilakukan pada MPPC untuk mendapatkan mesin actual yang dibutuhkan sebenarnya oleh CV. Atham Toys untuk melakukan kegiatan produksi mainan geometri 5 tumpuk, maka CV. Atham Toys dapat mempertimbangkan luas fasilitas mesin yang harus dibuat adalah dengan total luas 30.73 $\mathrm{m}^{2}$ dengan mempertimbangkan allowance sebesar $30 \%$ karena beban maksimum yang didapatkan adalah lebih besar dari $1.7 \mathrm{~m}^{2}$.

Hasil perhitungan luas lantai produksi yang dibutuhkan CV. Atham Toys pada tabel 7. berikut ini antara lain meja ukur $2.79 \mathrm{~m}^{2}$, mesin serut $5.8 \mathrm{~m}^{2}$, gerinda statis $1.16 \mathrm{~m}^{2}$, mesin cutting $6.96 \mathrm{~m}^{2}$, mesin amplas $3.8 \mathrm{~m}^{2}$, mesin router $6.3 \mathrm{~m}^{2}$, mesin bor $3.93 \mathrm{~m}^{2}$, spray gun $2.29 \mathrm{~m}^{2}$, meja kerja 3.33, dan meja packing $3.33 \mathrm{~m}^{2}$.

\section{Luas Gudang}

Pada CV. Atham Toys, terdapat dua gudang utama yakni gudang bahan baku dan gudang barang jadi. Untuk melakukan perhitungan luas gudang barang jadi diperlukan dimensi volume dari produk tersebut dan dimensi volume dari box yang akan digunakan. sehingga box yang diperlukan dalam gudang penyimpanan barang jadi untuk menyimpan produk yang telah selesai diproduksi adalah sebesar 7 box dengan luas gudang barang jadi yang harus dibuat oleh CV. Atham Toys sebesar $3.2 \mathrm{~m}^{2}$.

Produk yang telah selesai diproduksi akan dimasukan ke dalam gudang, untuk membuat sebuah gudang penyimpanan barang jadi pada CV. Atham Toys. Perhitungan luas gudang barang jadi diperlukan dimensi volume dari produk tersebut dan dimensi volume dari box yang akan digunakan. sehingga box yang diperlukan dalam gudang penyimpanan barang jadi untuk menyimpan produk yang telah selesai diproduksi adalah 
sebesar 7 box dengan luas gudang barang jadi yang harus dibuat oleh CV. Atham Toys sebesar $3.2 \mathrm{~m}^{2}$.

\section{Material Handling Planning Sheet (MHPS) dan Material Handling Cost}

Pada CV. Atham Toys, seluruh perpindahan bahan atau material dan bagian komponen produk (subassembly) hingga menghasilkan produk jadi dipindahkan secara manual tanpa menggunakan alat transportasi untuk material handling. Sehingga di dalam perhitungan biaya material handling tidak menggunakan asumsi biaya tambahan seperti biaya sewa alat transportasi, biaya perawatan, biaya depresiasi, biaya bensi atau oli, dan biaya lainnya. Untuk melakukan perhitungan biaya material handling pada produk mainan geomteri 5 tumpuk di CV. Atham Toys, maka data informasi yang diperlukan dapat dilihat pada Tabel 2 berikut ini.

Tabel 2. Data Informasi Pendukung Perhitungan Biaya Material Handling

\begin{tabular}{|c|c|}
\hline \multicolumn{2}{|c|}{$\begin{array}{c}\text { CV Atham Toys } \\
\text { Kanasitas Anokut Maksimal (unit) }\end{array}$} \\
\hline Bagian Base & 4 \\
\hline Bagian Pasak Tiang Kayu & 50 \\
\hline Bagian Biji & 625 \\
\hline Gaji Karyawan & $\operatorname{Rp} 2,850,000.00$ \\
\hline Per hari & $\operatorname{Rp} 118,750.00$ \\
\hline Per jam & Rp $16,964.29$ \\
\hline Per detik/m & $\operatorname{Rp} 4.71$ \\
\hline Per meter & $\operatorname{Rp} 23.56$ \\
\hline Waktu Operasional & 24 hari kerja/bulan , 7 jam/hari \\
\hline
\end{tabular}

Setelah menghitung seluruh komponen biaya material handling pada masing-masing fasilitas dan masing-masing komponen produk geometri 5 tumpuk pada CV. Atham Toys, maka total biaya material handling yang harus dikeluarkan oleh CV. Atham Toys dalam melakukan kegiatan produksi pembuatan mainan geometri 5 tumpuk adalah sebesar Rp. $87,839,-$

\section{Perancangan Usulan Tata Letak Lantai Produksi}

Perhitungan seluruh metode yang diuji dilakukan dengan menempatkan bobot material handling yang telah didapatkan pada masing-masing fasilitas di perhitungan MPPC yang disajikan dalam sebuah tabel From to Chart (FTC). Kemudian digambarkan kedekatan setiap stasiun kerja dengan Area Relationship Diagram (ARD). Setelah itu dilakukan pembuatan AAD (Area Allocation Diagram) yang merupakan dasar pembuatan plant layout. AAD dibuat berdasarkan ukuran stasiun kerja dan gudang yang telah dihitung sebelumnya kemudian menggunakan skala agar penggambaran lebih mudah. Kemudian diberikan gang sesuai dengan material handling yang digunakan. Setelah itu dihitung jarak rectilinier antar stasiun kerja. Efisiensi luas tata letak yang dihasilkan berdasarkan jarak rectilinear dengan metode terpilih yaitu graph base dihasilkan jarak sebesar 110 $\mathrm{m}^{2-}$ dengan efisiensi sebesar $81 \%$. Berikut pada Tabel 3 dan Tabel 4 adalah rekapitulasi perhitungan tersebut.

Tabel 3. Hasil Rekapitulasi Perhitungan Jarak Rectilinier

\begin{tabular}{cc}
\hline Metode & Jarak Rectilinear \\
\hline Hollier 1 & 148 \\
Hollier 2 & 148 \\
Grap Base & 110 \\
VIP Plantop & 298 \\
Pairwise & 151 \\
\hline
\end{tabular}


Tabel 4. Efisiensi Jarak Luas Tata Letak Berdasarkan Jarak Rectilinear

\begin{tabular}{cc}
\hline Total Luas Sebelum & $135 \mathrm{~m}^{2}$ \\
Total Luas Sesudah & $110 \mathrm{~m}^{2}$ \\
Efisiensi & $81 \%$ \\
\hline
\end{tabular}

\section{Perancangan Fasilitas Kantor}

Untuk melakukan sebuah perancangan fasilitas tata letak kantor pada CV. Atham Toys, maka diperlukan pembuatan struktur organisasi yang dapat menggambarkan jumlah karyawan laki-laki maupun karyawan perempuan yang bekerja pada perusahaan dan menggambarkan job description atau gambaran pekerjaan yang dilakukan pada setiap divisi dari mulai top management, middle management, hingga first line management.

\begin{tabular}{cc} 
Tabel 5. Jumlah Karyawan CV. Atham Toys \\
\hline Jenis Kelamin Karyawan & Jumlah \\
\hline Laki- Laki & 20 \\
Perempuan & 8 \\
Total & 28 \\
\hline
\end{tabular}

Selanjutnya akan ditentukan tingkat hubungan keterkaitan dari masing-masing divisi, dalam hal ini seluruh divisi akan berkoordinasi dengan divisi lainnya untuk melakukan sebuah pekerjaan melalui tanggung jawab pada job description yang telah dilaksanakan di CV. Atham Toys (Tabel 6).

Tabel 6. Task Interpendency dan Coordination Level pada CV. Atham Toys

\begin{tabular}{|c|c|c|c|c|c|}
\hline No & Nama Bagian & Divisi Ketergantungan & $\begin{array}{c}\text { Jenis } \\
\text { Ketergantungan }\end{array}$ & $\begin{array}{c}\text { Tingkat } \\
\text { Koordinasi }\end{array}$ & Level \\
\hline 1 & CEO & Manager KA Produksi & Bolak balik & Tinggi & A \\
\hline 2 & $\mathrm{CEO}$ & Manager Keuangan & Bolak balik & Tinggi & A \\
\hline 3 & $\mathrm{CEO}$ & Manager HRS & Bolak balik & Tinggi & $\mathrm{E}$ \\
\hline 4 & CEO & $\mathrm{R} / \mathrm{D}$ & Bolak balik & Tinggi & I \\
\hline 5 & Manager KA Produksi & Supervisor/Staff KA Produksi & Bolak balik & Tinggi & $\mathrm{O}$ \\
\hline 6 & Manager Keuangan & Staff Keuangan & Bolak balik & Tinggi & A \\
\hline 7 & Manager HRS & Staff HRS & Bolak balik & Tinggi & A \\
\hline 8 & Manager R/D & Staff R/D & Bolak balik & Tinggi & A \\
\hline 9 & Supervisor/Staff KA Produksi & Manager KA Produksi & Bolak balik & Tinggi & A \\
\hline 10 & Staff KA Produksi & Operator Mesin Ukur & Mengumpul & Rendah & I \\
\hline 11 & Staff KA Produksi & Operator Mesin Serut & Mengumpul & Rendah & $\mathrm{O}$ \\
\hline 12 & Staff KA Produksi & Operator Mesin Statis & Mengumpul & Rendah & I \\
\hline 13 & Staff KA Produksi & Operator Mesin Cutting & Mengumpul & Rendah & $\mathrm{O}$ \\
\hline 14 & Staff KA Produksi & Operator Mesin Amplas & Mengumpul & Rendah & $\mathrm{O}$ \\
\hline 15 & Staff KA Produksi & Operator Mesin Router & Mengumpul & Rendah & $\mathrm{O}$ \\
\hline 16 & Staff KA Produksi & Operator Mesin Bor & Mengumpul & Rendah & $\mathrm{O}$ \\
\hline 17 & Staff KA Produksi & Operator Sray Gun & Mengumpul & Rendah & $\mathrm{O}$ \\
\hline 18 & Staff KA Produksi & Operasi Meja Kerja & Mengumpul & Rendah & $\mathrm{O}$ \\
\hline 19 & Staff KA Produksi & Operasi Meja Packing & Mengumpul & Rendah & $\mathrm{O}$ \\
\hline
\end{tabular}

Pada Tabel 7 dan Gambar 3, seluruh divisi akan berkoordinasi dengan divisi lainnya dalam mengerjakan suatu pekerjaan hingga pekerjaan tersebut dapat selesai dikerjakan dan berkoordinasi untuk menyelesaikan suatu permasalahan perusahaan.

Tabel 7. Sandi Kualitatif dan Kode Warna ARC (Area Relationship Chart)

\begin{tabular}{cccc}
\hline Sandi Kualitatif & Ketergantungan & Kode Warna & Activity Relationship Chart \\
\hline A & Absolut & Merah & \\
E & Istimewa & Orange & \\
I & Penting & Hijau & \\
O & Biasa & Biru & \\
U & Tidak Penting & Putih & \\
X & Tidak Dikehendaki Berdekatan & Coklat & \\
\hline
\end{tabular}




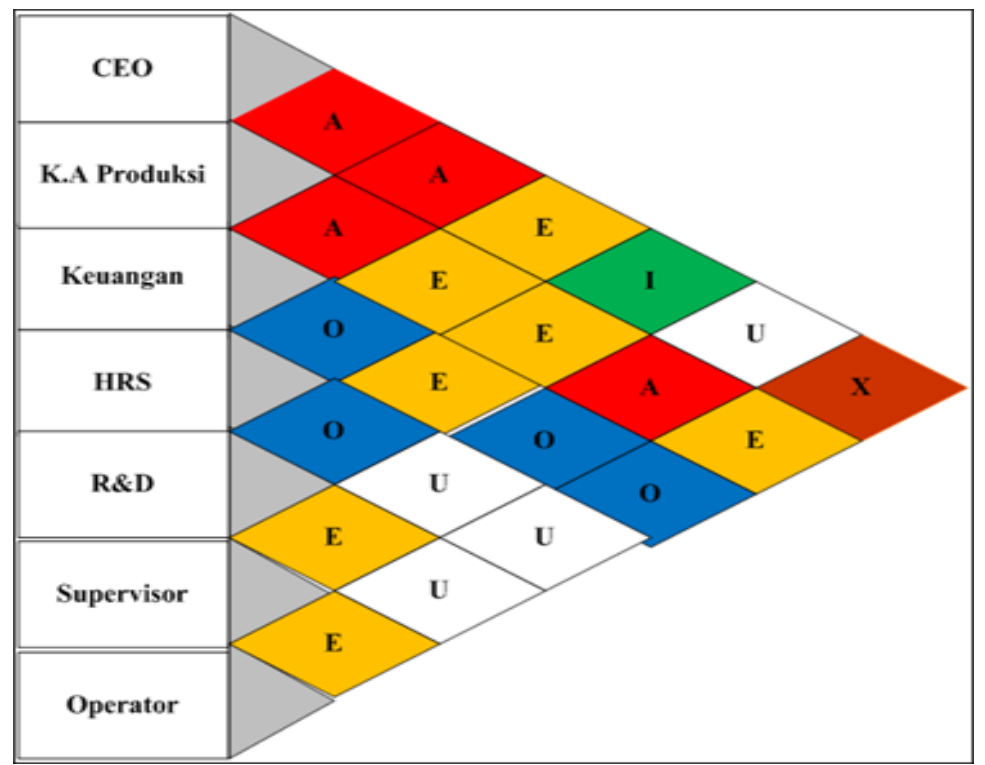

Gambar 3. Diagram Activity Relationship Chart pada Divisi Karyawan di CV. Atham Toys

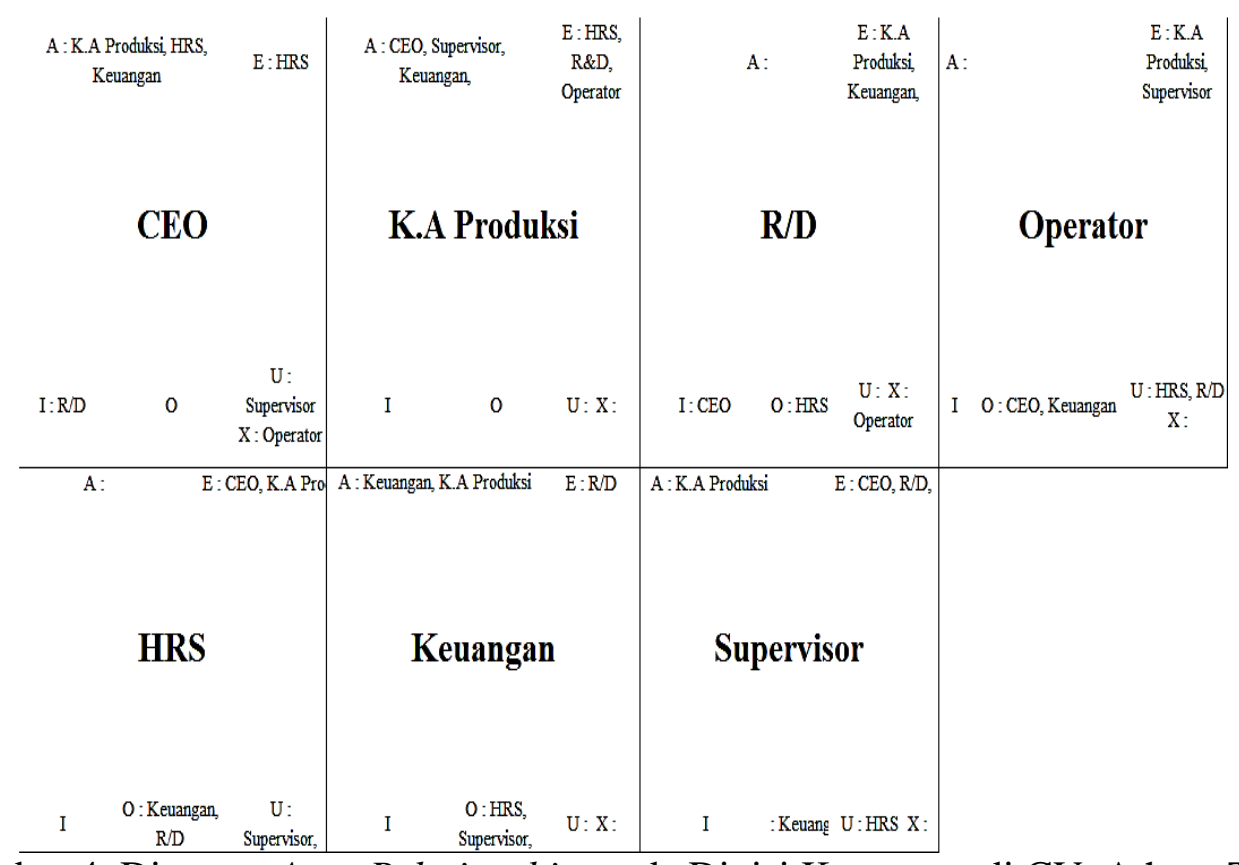

Gambar 4. Diagram Area Relationship pada Divisi Karyawan di CV. Atham Toys

Setelah menentukan sandi kode warna dan membuat diagram ARC (Gambar 3), maka tingkat ketergantungan yang telah dibuat akan direpresentasikan dalam diagram ARD dalam perancangan fasilitas kantor, sehingga sebuah divsi akan mengetahui seberapa sering divsi tersebut akan melakukan koordinasi dengan divisi lainnya dalam mengerjakan suatu pekerjaan (Gambar 4).

\section{Perancangan Fasilitas Penunjang}

Fasilitas penunjang yang digunakan oleh CV. Atham Toys antara lain parkir, kamar mandi/restroom, dapur, kantor, dan mushola. Setelah itu menentukan hubungan setiap fasilitas penunjang disimbolkan dengan huruf-huruf yang melambangkan kedekatan setiap fasilitas. Setelah itu dibuat diagram ARC seperti yang ada di Gambar 5. 


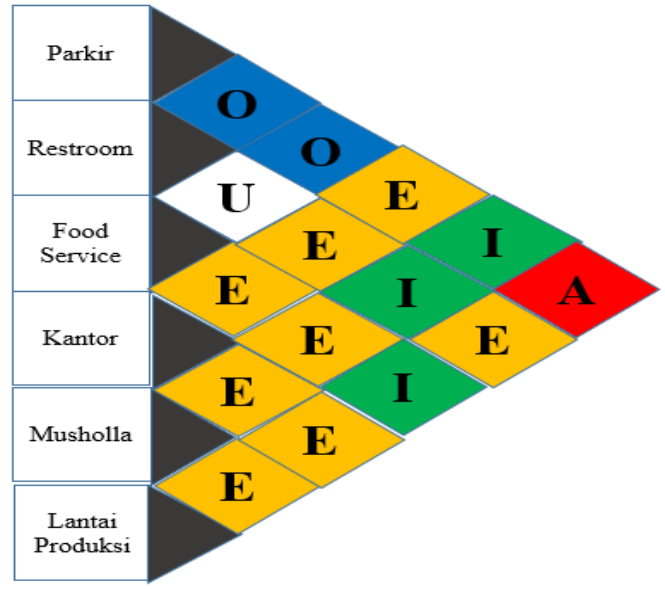

Gambar 5. ARC (Area Relationship Chart) dari setiap Fasilitas yang ada di CV. Atham Toys

Perancangan ARC digunakan untuk merencanakan dan menganalisis keterkaitan antar kegiatan. Namun, dengan ARC belum memperoleh gambaran tentang letak suatu fasilitas relatif terhadap fasitlitas lainnya. Oleh karena itu, dibutuhkan ARD untuk mendapatkan gambaran tentang tata letak suatu departemen relatif terhadap departemen lainnya. kemudian dilakukan perancangan ARD berdasarkan data-data yang telah didapatkan sebelumnya. Berikut pada Gambar 6 adalah hasil ARD tersebut.

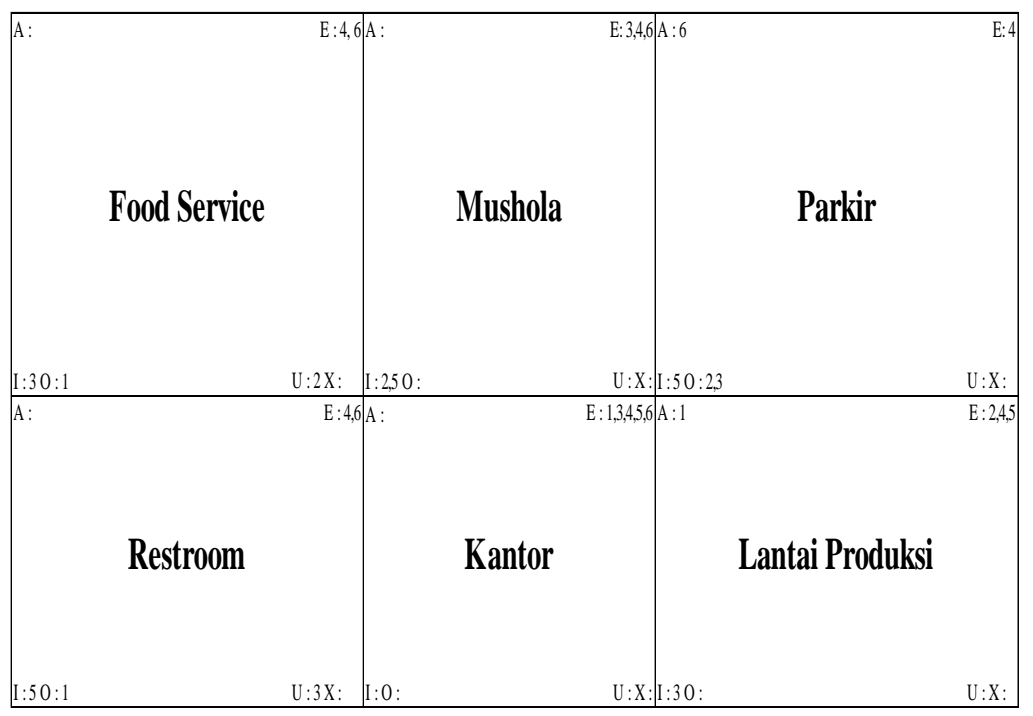

Gambar 6. ARD (Area Relationship Diagram)

Penentuan Lokasi Pabrik dengan Menggunakan Metode Analytical Hierarchy Process

Untuk melakukan usulan dalam penentuan lokasi pabrik pada CV. Atham Toys, kriteria yang digunakan dalam menentukan lokasi pabrik antara lain lokasi pasar, harga tanah, harga bangunan atau gedung, biaya distribusi barang jadi, biaya pengangkutan bahan baku, biaya pengangkutan bahan pembantu, biaya pengangkutan komponen pembantu, ketersediaan bahan baku, lokasi sumber bahan baku, lingkungan masyarakat, tingkat upah buruh di daerah tersebut, fasilitas umum, tersedianya utilitas (tenaga, bahan bakar, air, buangan, komunikasi, dll), dan persediaan tenaga kerja. untuk alternatif yang dapat dipilih dalam menentukan lokasi pabrik antara lain daerah Tangerang, Bekasi, Jakarta, dan Sukabumi. 


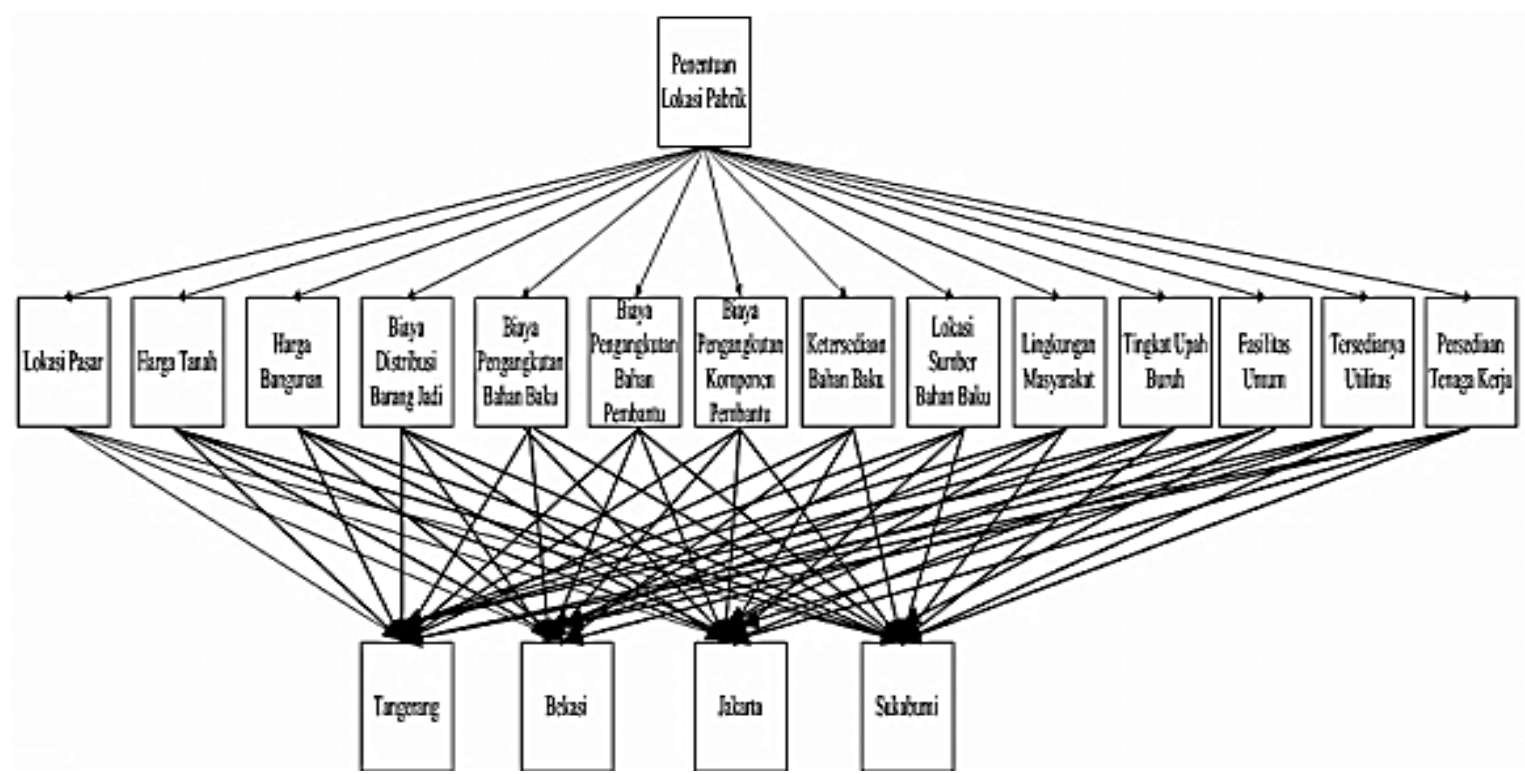

Gambar 7. Stuktur Hirarki Penentuan Lokasi Pabrik CV. Atham Toys

Pakar yang dipilih merupakan orang yang ahli dibidangnya, dapat dipercaya, dan memutuskan sesuatu dengan benar dan baik dalam penentuan kriteria solusi dari permasalahan penentuan lokasi pabrik di daerah Tangerang, Bekasi, Jakarta, dan Sukabumi. Pakar pertama merupakan pemilik atau CEO dari CV. Atham Toys yaitu Ahmad Thamrin. Pakar kedua merupakan asisten praktikum Perancangan Tata Letak Pabrik yang bernama Setobayu. Pakar ketiga merupakan asisten praktikum Perancangan Tata Letak Pabrik yang bernama Frida Aprilia. Hasil perhitungan AHP menurut pakar ketiga adalah konsisten karena nilai Consistency Ratio (CR) atau Inconsistency yaitu 0,1 tidak lebih besar atau sama dengan dari Consistency Index (CI), yaitu 0,1.

Berdasarkan Gambar 8, prioritas alternatif yang dapat dipilih dalam menentukan lokasi pabrik menurut kombinasi pendapat dari seluruh pakar adalah di daerah Tangerang dengan bobot 0,353 atau 35,3\%, daerah Bekasi dengan bobot 0,332 atau 33,2\%, daerah Jakarta dengan bobot 0,202 atau 20,2\%, dan daerah Sukabumi dengan bobot 0,103 atau $10,3 \%$.

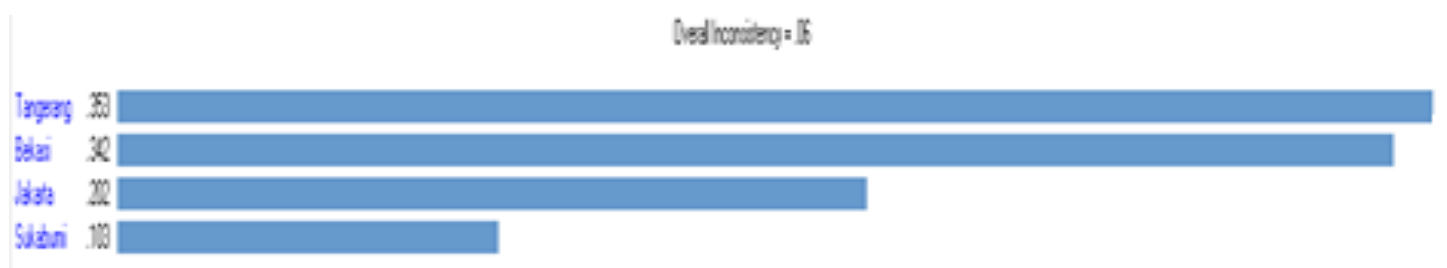

Gambar 8. Hasil Prioritas Alternatif Perhitungan AHP Kombinasi Seluruh Pakar

Hasil perhitungan AHP menurut tersebut adalah konsisten karena nilai Consistency Ratio (CR) atau Inconsistency yaitu 0,06 tidak lebih besar atau sama dengan dari Consistency Index (CI) yaitu 0,1

Berdasarkan Gambar 9, prioritas utama dari kriteria yang dapat dipilih dalam menentukan lokasi pabrik menurut pendapat seluruh pakar adalah lokasi pasar dengan bobot 0,122 atau $12,2 \%$ dan prioritas akhir yang dapat dipilih adalah persediaan tenaga kerja dengan bobot 0,027 atau $2,7 \%$. 


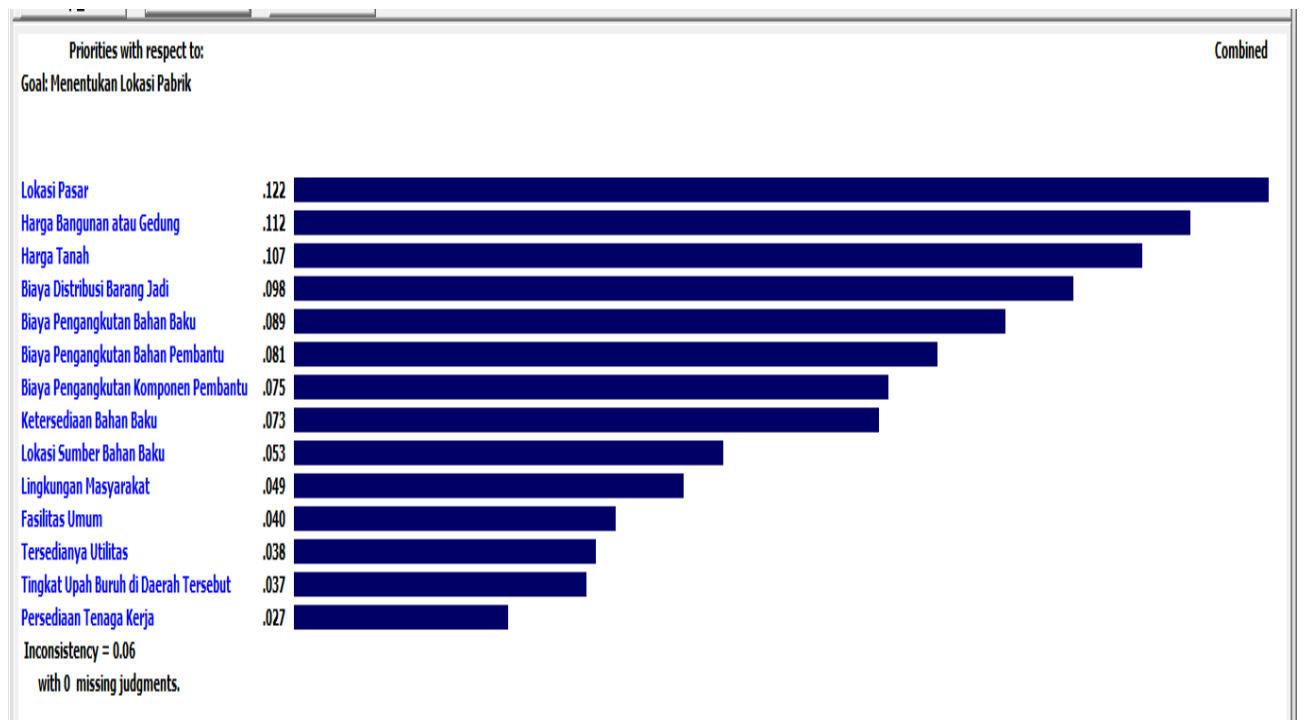

Gambar 9. Hasil Prioritas Kriteria Perhitungan AHP Kombinasi Seluruh Pakar

\section{KESIMPULAN DAN SARAN}

Berdasarkan hasil perhitungan yang telah dilakukan untuk membuat tata ulang dari layout pabrik CV. Atham Toys didapatkan untuk metode yang paling efektif dan efisien berdasarkan jarak rectilinear terkecil adalah metode Graph Based Construction dengan total jarak rectilinearnya sebesar $110 \mathrm{~m}$. Lalu untuk luas keseluruhan pabrik adalah sebesar $135,870 \mathrm{~m}^{2}$ yang terdiri dari luas lantai produksi sebesar $65,94 \mathrm{~m}^{2}$, luas fasilitas lainya seperti kantor, toilet, dapur, mushola, ruang serba guna, dan parkir adalah sebesar 69,93 $\mathrm{m}^{2}$. Setelah itu untuk pemilihan lokasi pabrik yang telah ditentukan berdasarkan kriteria yang dinilai oleh keempat pakar yang diolah dengan menggunakan metode AHP. Maka hasil yang didapat untuk lokasi pabrik yang paling strategis adalah di Tangerang yaitu $35,3 \%$.

\section{Daftar Pustaka}

[1]. Wignjosoebroto, Sritomo, 2003, Tata Letak Pabrik dan Pemindahan Bahan, Edisi ke 3 , Guna Widya, Surabaya.

[2]. Apple, J.M.. 1990. Tata Letak Pabrik dan Pemindahan Bahan, Edisi ke 3, ITB, Bandung.

[3]. Karonsih, S. N., Setyanto, N. W., dan Tantrika, C. F. M., 2010, Perbaikan Tata Letak Penempatan Barang di Gudang Penyimpanan Material Berdasarkan Class Based Storage Policy, Jurnal Teknik Industri, 345 -357.

[4]. Sarwanto, W., 2011, Pembuatan Tata Letak Ruang Produksi Coklat Isi Dodol Sebagai Pengembangan Produk di CV. Mubarokfood Cipta Delicia- Kudus, Tugas Akhir: Program Studi Teknologi Industri Pertanian Universitas Gadja Mada, Yogyakarta. 